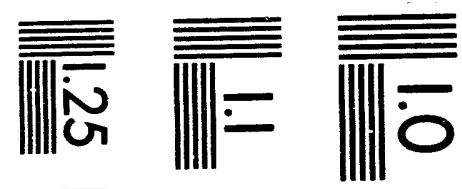

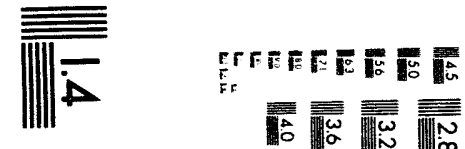

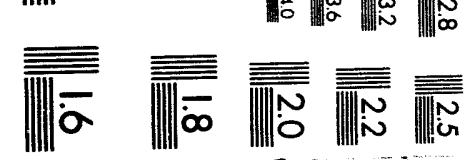



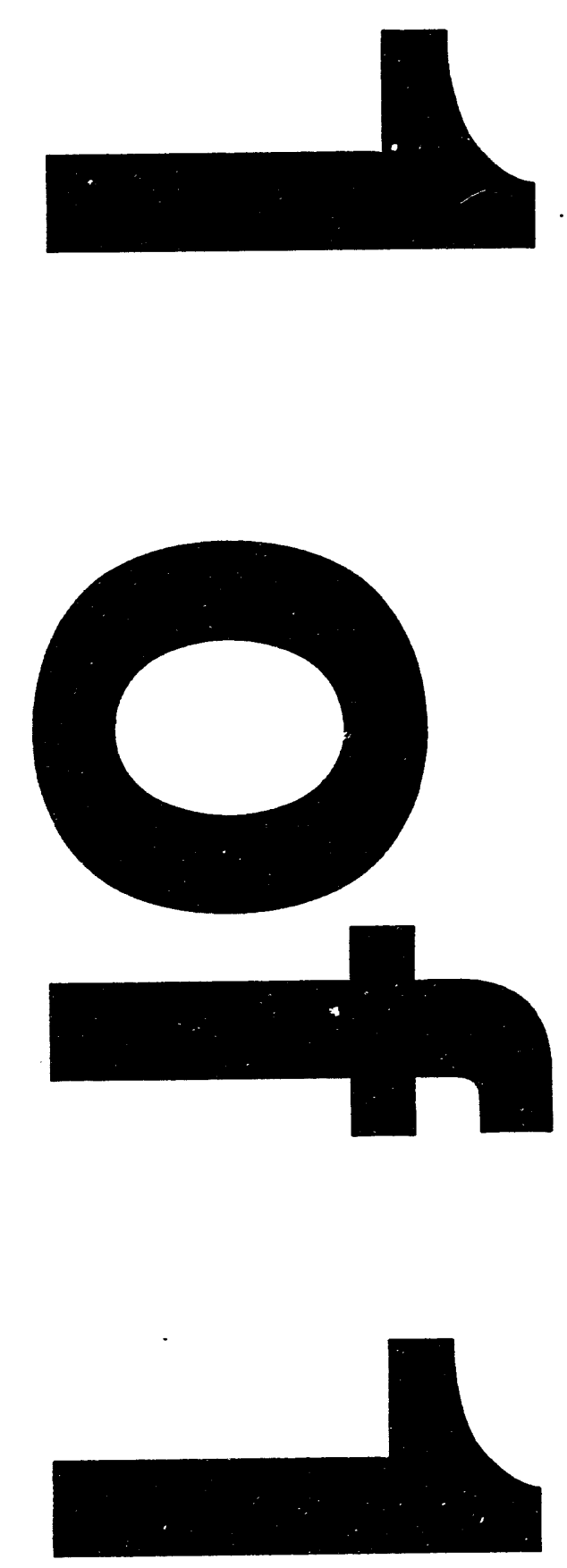


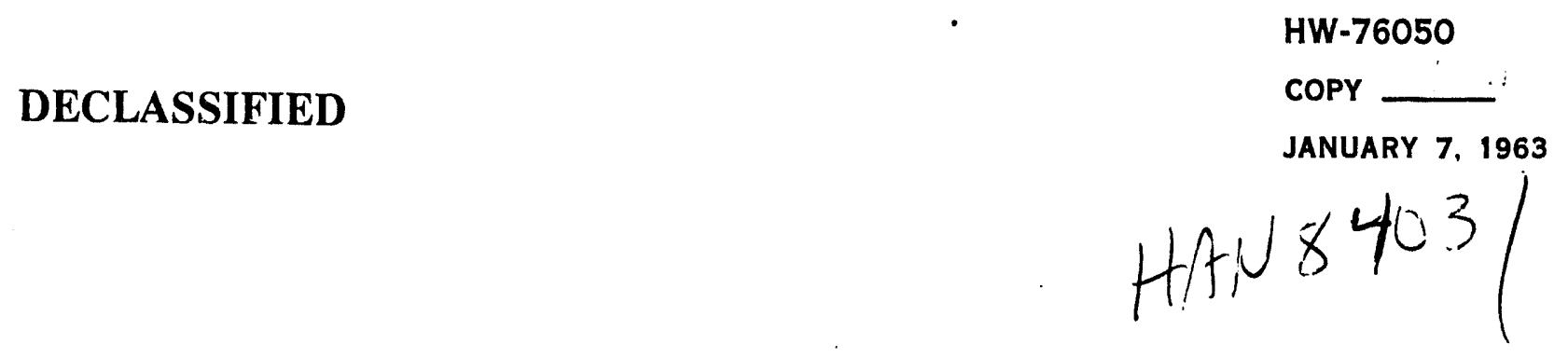

$\mathrm{N}$ - REACTOR DEPARTMENT
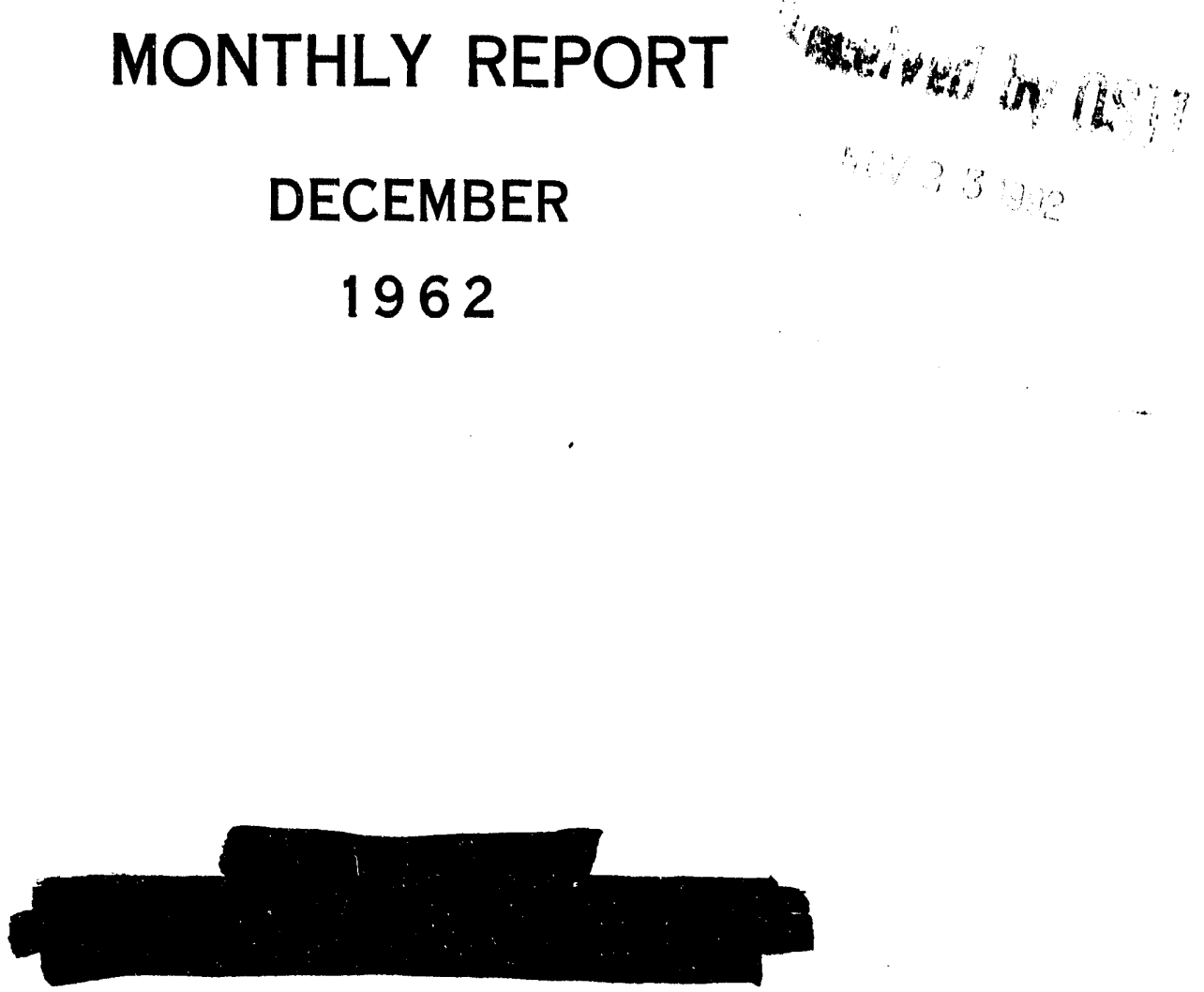

HANFORD ATOMIC PRODUCTS OPERATION RICHLAND. WASHINGTON
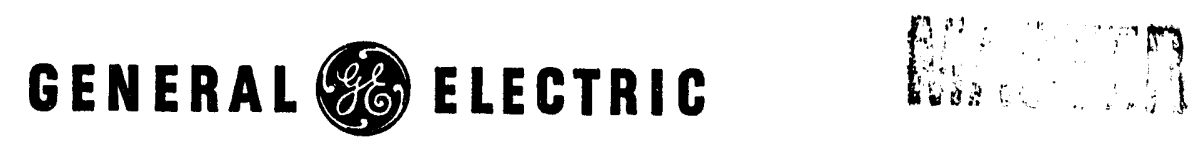
This document consists of

N-REACTOR DEPARTMENT

MONTHLY REPORT - - DECEMBER 1962

Compiled by $\mathrm{N}$-Reactor Department

January 7, 1963 - Richland, Washington

Work performed under Contract No. AT(45-1) - 1350 between the Atomi a Energy Commission and General Electric Company.

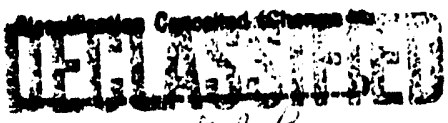

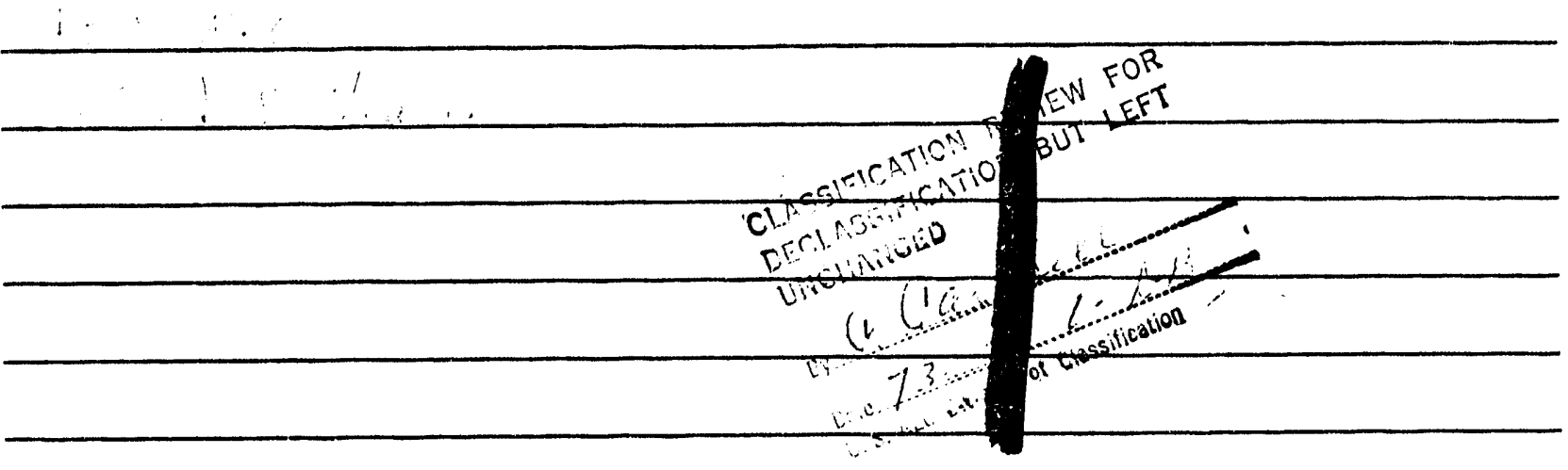




\section{DISTR IBUT ION}

Copy Number

1
2
3
4
5
$6,7,8$
9,10

11
12
13
14
15
16
17
18
19
20
$21,22,23$
24
25

W. E. Johnson

R. L. Dickeman

A. B. Greninger

H. M. Parker

H. D. Tibbals

J. E. Trav1s, AEC-HOO

F. P. Baranowski

$$
\begin{aligned}
\text { Director - Division of Production } \\
\text { Washington 25, D.C. }
\end{aligned}
$$

F. E. Crever

Savannah River Operations Office

F. H. Belcher - St. Louis Area Office

C. L. Karl - Fernald Area Office

J. W. Ruch - Oak Ridge Operations office

M. C. Leverett

L. Mo Loeb

W. M. Mathis - J. S. McMahon

J. Milne

C. O. Steinnagel

Extra Copies

300 Files

Records Service Center

TABLE OF CONTENTS

General Summary

N-Reactor Fuels Operation

Research \& Engineering Operation

Financial Operation

N-Reactor Project Operation
A-1 thorugh A-8

B-1 through B-20

C-1 throligin C-4

D-1 through D-2

E-1 through E-11 
GENERAL SUMMARY

N-REACTOR FUELS

Manufacturing

Production

An input of 26.1 tons resulted in 131 production extrusions during December of which 114 were outers and 17 inners. Total input to date is 272.6 tons or about $43 \%$ of first load requirements. First run shop yield for December was $59.0 \%$ for outers, $26.4 \%$ for inners for a total yield of $49.1 \%$.

\section{General}

Bonding difficulties encountered with inner extrusions late in November resulted in a predominant input of outer material. The problem is not completely resolved; however, it appears that uranium is the problem, rather than the process.

Lack of supports continued to prevent processing of material through final steps of the process.

A false Criticality Incident alarm occurred on December 8 as a result of a faulty photomultiplier tube. Fortunately, it occurred on a week end when no material was being processed.

\section{Engineeririg}

\section{Test Fuel Fabrication}

A charge of fourteen NAE-I fuels is on the shelf at the KE Reactor ready for charging. Ten seventeen-inch NIE-I fuels with shroud tubes are available for use as heater elements with the "crud" test. One thirteen-element charge of KSE-5 fuel elements is complete and avallable for charging.

\section{Materials Development}

A specific feed-site test has been designed to evaluate gains made in ingot concentricity. The test will involve processing up to 36 ingots that have been Iaced and chamfered. An additional six solid cast and drilled ingots will be machined on the O.D. until concentric, end faced and chamfered.

\section{Coextrusion Process}

Current major problem is complete lack of bonding on NIE extrusion. Development testing indicates that uranium billet geometry has an effect on bonding. Tests to isolate exact cause or causes are being designed.

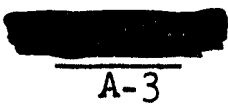




\section{Cherical Process}

Initial production using standard rework process for salvaging fuels with ore reject end closure resulted in severe pitting of the end closure exposed to reprocessing. Pilot plant tests were initiated, and these tests showed that: (1) the pitting is caused by localized attack on the end closure weld by the chemical milling solution, and (2) the welds can be protected during chemical milling by coating with Amercoat No. 33 acid-resistant paint.

The mos't common contaminants on autoclaved fuel elements currently in final storage in the 333 Building production facility are shop dirt and fingerprints. Several cleaning techniques are being evaluated, including vapor degreasing, steam cleaning, alkaline soak cleaning and organic solvent clearing.

\section{End Closure Development}

Twelve each NOE and NIE fuel elements were brazed using alloy made with zircorium in lieu of zircaloy. Preliminary tests indicate that zirconium may be used successfully in the fabrication of brazing alloy.

Recent developments indicate that weld cracking will not occur even with a narrow ( 20 mils) braze line if the weld technique is changed to minimize mixing of the braze alloy in the weld. Optimum welding techniques for this process are being developed.

\section{Fuel Element Supports}

As stated in last month's report, it is planned to convert from the "suitcase handle" type support to "arch type" as soon as possible. Major activity has been in fabricating strip and forming supports. A source of adequately ductile strip has not yet been established and HLO is currently rolling strip from split cladding shells.

\section{Testing Methods}

The routine operation of fuel teaters has continued to be flagued by downtime. The welder interference problem has been reduced by bullding grounding, and the purchase of spare parts for critical equipment will reduce downtime.

\section{N-REACTOR PROJECT}

Designs for the minimum cost - Iimited life Emergency Dump System - were forwarded to Kaiser Engineers on December 14, 1962. The CPFF estimate is $\$ 195,000$, versus the goal of $\$ 250,000$. The design of the Chemical Waste Storage System, with one tank deleted, was also forwarded on December 14, 1962. 
The specification and 31 drawings for the Hot Water Quality Laboratory equipment wer : revised to transfer design responsibility from Burns and Roe to General Electric and to effect a cost reduction estimated to be over $\$ 40,000$,

Custody of certain 100-N plant facilities were transferred from Kaiser Engineers to General Electric Company on December 17, 1962. Specific facilities involved in this transfer are 108, 151, 153, 163, 166, 181, 183, 184 and those portions of the 182, 1503 and 1900 Area systems which are required to provide operational continlity in the major facilities enumerated.

Work on the general mechanical features in the 105-N Building under Subcontract SC-78 by Harder Industrial was completed December 1, 1962.

Installation of the butterfly valves on the left inlet pipe headers has been basically completed except for about 30 where repair of the Grayloc hub seal surfaces is required on the neader rozzles.

All ball safety system trip mechanisms and plug assemblies have been installed in the top shield of the reactor.

\section{RESEARCH \& ENGINEERTIIG}

NPR Production ard Cost Study

This study, which includes projections for the ten year period ending in 1972, shows the N-Reactor to be capable of economic production of plutonium, power and several 1sotopes, including $\mathrm{Np}-237$. A study of the effect of tritium production on costs is as yet incomplete.

Thermal Hydraulics Research Program

A program proposal has been drawn up for the acquisition of data in the 189-D facility on NPR connectors and plugged fuel element flow and pressure drop characteristics.

Nuclear Healtin and Safety

Volume II of tine NPR Hazards Review was issued.

\section{Projest Representatives Activities}

The design concept and preliminary detail design for the Emergency Dump Basin has been reviewed and accepted by Research \& Engineering Project Representatives.

The following operating concepts prepared by Burns and Roe, Inc., were reviewed and accepted for design by Project Representatives: Emergency Seal Water Concept; Once-Through Cooling Concept; Modal Station Concept; ChargeDischarge Concept.
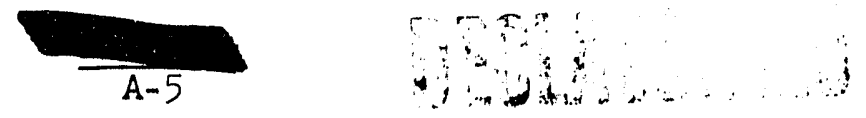
Irradiation Testing in Support of $\mathrm{N}$-Reactor Fuels

A test to provide information for guidance in $N$-Reactor primary piping prestartup cleaning procedures has been issued and is planned for KKR Loop \#I. A charge of elght, 17-inch $\mathrm{N}$ inner tubes to test bonded and unbonded end closures, has reached an exposure of $420 \mathrm{MWD} / \mathrm{T}$. Discharge at an exposure of $2500 \mathrm{MWD} / \mathrm{T}$ is planned for April, 1963.

KER Loop \#3 is out of service for pump repair. Fourteen $\mathbb{N}$ prototypic fuel elements in KER Loop \#4 have reached an exposure of $620 \mathrm{MWD} / \mathrm{T}$. Goal exposure of about $2100 \mathrm{MWD} / \mathrm{T}$ should be reached by June, 1963.

PERSONNEL STATISTICS

Number of employees as of December 1, $1962 \quad 405$

Number of employees as of December 31, 1962

414

Exempt

Nonexempt Total

General

Financial

N-Reactor Fuels

N-Reactor Plant

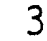

Research \& Engineering

N-Reactor Project

11

51

21

44

88

$\begin{array}{r}1 \\ 7 \\ 104 \\ 6 \\ 55 \\ 23 \\ \hline\end{array}$

4

18

155

27

99

111

TOTALS

Employment

Additions :

Reductions:

Net Addition:
11 Nonexempt

2 Nonexempt

9

The net addition of nine employees consisted of seven Power Operators and two secretaries. There was no change in exempt employees.

\section{STAFF}

\author{
General Manager \\ Manager, Employee Relations \\ Manager, Finance \\ Manager, Research \& Engineering \\ Manager, N-Reactor Plant \\ Manager, N-Reactor Project \\ Manager, N-Reactor Fuels
}
R. I. Dickeman
C. O. Steinnagel
J. Milne
M. C. Leverett
W. M. Mathis
J. S. McMahon
L. M. Loeb 


\section{SAFETY}

Days since last disabling injury

Hours worked since last disabling injury

$64 \quad 006$

MEDICAL TREATMENT INJURIES

\begin{tabular}{cc}
\hline \multicolumn{3}{c}{ Current Month } \\
\hline $\begin{array}{c}\text { No. of } \\
\text { Cases }\end{array}$ & $\begin{array}{c}\text { Frequency } \\
\text { Rate }\end{array}$ \\
\cline { 2 - 2 } 1 & 3.45 \\
6 & 2.27 \\
4 & 2.65 \\
3 & 1.83 \\
0 & -0 \\
14 & \\
\hline
\end{tabular}

SECURITY

There were no security violations in the Department during December, 1962.

SUGGESTION PLAN

$\begin{array}{ccccc}\text { Number } & \text { Number } & \text { Number } & \text { Amount } & \text { Net Annual } \\ \text { Reserved } & \text { Evaluated } & \text { Adopted } & \text { of Awards } & \text { Savings }\end{array}$

Operation

Mo, CYTD MO. CYTD MO. CYTD

Mo. CYTD

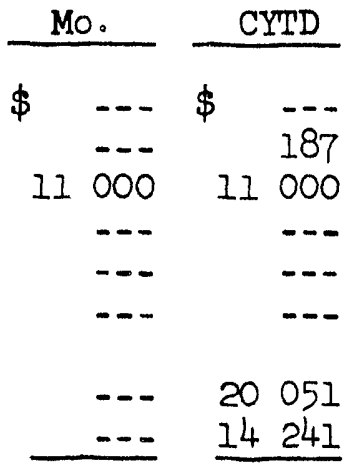

General

Financial

N-Reactor Fuels

N-Reactor Plant

-.-

$\$$

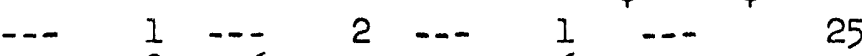

$\begin{array}{llllllll}15 & 18 & 6 & 9 & 5 & 6 & 790 & 795\end{array}$

-.-

N-Reactor Project

Research \& Eng'g

Manufacturing

(to $12-1-62$ )

Plant Facilities

-.-

-. $-\cdots,-\cdots \quad-$

-. $29 \begin{array}{llllllll} & 298 & \ldots & 281 & \ldots & 134 & \ldots & 330\end{array}$

TOTAL

$=173=-\cdots \quad 258 \quad \cdots \quad 127 \quad \cdots \quad 2730$

$\$ 11000 \$ \underline{\underline{45479}}$

The tabulation set forth above combines Fuels Preparation and N-Reactor Departments for this month only in order to reflect the aggregate CY activity of these groups. 
COST IMPROVEMENTSS (EXCLUDING SUGGESTIONS)

Operation

General

Manufacturing

N-Reactor Fuels-1)

N-Reactor Plant

N-Reactor Project

Research \& Engineering

Plant Facilities

TOTAL
Accepted in December

$\$ 131026$

131026

-..

$-\cdots$

$---$

$\cdots$

$\$ 131026$

GOAL

Total Accepted CYTD

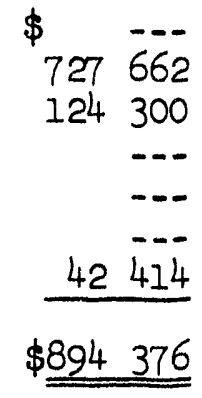

$\$ 900000$

$99.4 \%$

PER CENT GOAL ACHIEVED

The tabulation combines FPD and N-RD for this month only to reflect the achievement to goal for FPD for CY 1962.

\section{PATENT SUMMARY - DECEMBER 1962}

All persons engaged in work that might reasonably be expected to result in inventions, or discoveries, advise that, to the best of their knowledge and belief, no inventions or discoveries were made in the course of their work during November. Such persons further advise that, for the period therein covered by this report, notebook records, if any, kept ir the course of their work have been examined $f a$ possible inventions or discover:es.

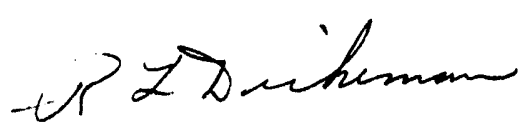

General Manager

N-Reactor Department

RL Dickeman: skd 


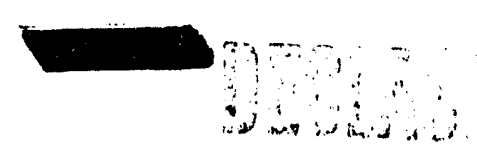

\section{N-REACTOR FUELS OPERATION}

DECEMBER 1962

VISITORS

Name

Paul Berner

AM Van Vorst

DM Guy

J Coyne

CR Jackson

RV Stanley

RW Clark

TRIPS

GW Riedeman

n

DW Darsow

NC Davis
Company

Star Machinery Co., Seattle, Washington

ALCOA, Seattle, Washington

EF Houghton \& Co., Seattle, Washington

Stanley Enterprises, Seattle, Washington

General Electric Co., Manufacturing Services, Schenectady, New York
Contact

TB Correy

HP Kraemer

DW Darsow

TR Groupman

TB Correy
Rem, Inc., Portland, CA Brown Oregon

Wah Chang Corp., Albany, Oregon

Wilkins and Assoc., R Wilkins Tacoma, Washington

Western Pneumatic Tube $R$ Walsh Co., Kirkland, Wash.

Alaskan Copper \& Brass $\mathrm{K}$ Rosen Co., Seattle, Wash.

Rem, Inc., Portland, Oregon

Wah Chang Corp., Albany, Oregon
CA Brown

RA Graham
$12 / 4$

Discuss material procurement

12/18- Discuss welding $12 / 20$ problems and development

$12 / 5$

12/5 Cu-Si plates and sleeves.

12/5 Cu-Si sleeves

12/6 Cu and Cu-Si components

12/18- Monitoring tooling $12 / 19$

$12 / 20$ Observe rolling techniques 
Name

HP Kraemer

DW Darsow

$"$$$
\text { " }
$$

$n$

"

\section{Company}

Rem, Inc., Portland, Oregon

Airline Welding and Engineering, Gardena, California

Anaconda American Brass Co., Los Angeles, California

Ducommun Metals \& Supply EP Iady Los Angeles, Calif.

Harvey Aluminum, Inc. Torrance, California
Contact

CA Brown

H. Meredith

HA Buckbee

12/27 Cu-Si sheet

G. Christensen 12/28 G. Moudry

Date Reason

12/27 Cu-Si sleeves

12/27 Cu-Si sheet

12/19 Zirconium supports

Zirconium component

PERSONNEL

Additions

D. R. Wild, Manufacturing Training Program, transferred to Manufacturing, Methods Engineering, effective December $31,1962$.

B. D. Hopkins, Technical Graduate, transferred to Quality Control, Process Control, effective December 1, 1962.

$\underline{\text { Removals }}$

T.M. Anstett, Manufacturing Training Program, transferred from Manufacturing, Methods Fngineering to Maintenance Operation, IPD, effective December 17, 1962.

\section{INVENTIONS}

All Engineering personnel engaged in work that might reasonably be expected to result in inventions or discoveries advise that to the best of their knowledge and belief, no inventions or discoveries were made in the course of their work during December, 1962. Such persons further advise that for the period therein covered by this report, notebook records, if any, kept in the course of their work have been examined for posibible inventions or discoveries.

\section{SIGNIFICANT REPORTS}

HW-75884, "Nondestructive Testing - Engineering Audit Reports - AlSi Shop Operation for November," C. J. Denton, December 13, 1962 (Unclassified).

"Report of the Working Committee of the Fuel Element Development Committee," S. M.Gill, December 26, 1962 (Confidential-Undocumented).

"Summary-Inner Tube Bonding Problem," C. H. Shaw, December 28, 1962 (Confid-Undoc) SECURITY VIOLATIONS

There were no security violations in the N-Reactor Fuels Operation during December. Total CYTD - 0 . 
MANUFACTURING

\section{Production - Coextrusion Shop}

A total of 131 production extrusions were made during December, of which 17 were inner tubes and 114 were outer tubes. An additional 33 special extrusions were completed for Engineering. The production extrusions represent an input of 26.1 tons and brings the total input to 272.6 tons or roughly 43 per cent of the first load requirements.

Input was predominantly outer material due to a continuation of bonding difficulties encountered with inner material late in November. The problem is not completely resolved, however it appears that uranium is the problem rather than the process.

Lack of supports continued to prevent the processing of material through the final steps of the process. A total of 498 inners and 666 outers was added to the backlog awaiting support welding. This brings the total awaiting supports to 5545 inners and 3674 outers, or 84.9 tons.

A total of 300 inner and 651 outer rework pieces was fed back into the production stream. This leaves a balance of 159 inners and 134 outers for reworking.

Production Statistics

Operation

Extrusion

Cutup First

Cutup Rework

Chemical Milling

Braze (ends)

Heat Treat

Machining

Vacu-Blast

Welding

End Test

Clad and Bond Test

Support Weld

Autoclaves

To Fina.l Inspection

\section{Inners}

17

445

305

779

1409

708

665

700

700

276

823

-

-

$-$
Outers

114

1463

285

1250

2106

1471

979

1091

1274

1059

1200

353

45

45
Total

1.31

1908

590

2029

3515

2179

1644

1791

1974

1785

2023

353

45

Oxide Burner - 69 batches $=786$ Ibs. 
Shop Yield - First Run

First Load to Date - December 31, 1962

Outer extrusions 2017 - 2815

Inner extrusions 1016 - 1601

Outer

Inner

Total

Tons Input

$137 \cdot 3$

69.4

206.7

Tons Output

a. Ready for Support Weld 46.4

13.3

b. Final Inspection

8.7

c. Final Storage

68.4

31.3

$77 \cdot 7$

0.4

13.7

Total

$49.8 \%$

36.0

13.0

Percent Yield

$51.9 \%$

$50.5 \%$

Yield for December, 1962 - First Run

Outer extrusions $2745-2815$

Inner extrusions 1557 - 1601

Tons Input

12.2

$5 \cdot 3$

$17 \cdot 5$

Tons Output

a. Ready for Support Weld

6.8

1.4

8.2

b. Final Inspection

0.4

0.0

0.4

c. Final storage

$\frac{0.0}{7.2}$

$\frac{0.0}{1.4}$

0.0

Total

$59.0 \%$

$26.4 \%$

$49.1 \%$

\section{Plant Operation}

An Appropriation Request is being processed for additional inner autoclave baskets as a result of the decision to autoclave inners and outers separately. The additional baskets will be required to meet current production forecasts.

A new layout was made for the final inspection area. The area was painted white and steps are underway to make this into a white glove area.

Weight gain coupons were supplied by Process Control and are now being processed with each autoclave charge. The autoclave lift assemblies are being raised five inches to keep fuel tubes above the cold zone in the bottom of the vessels.

Both the support welders and the locking clip welder have been converted to new type grounding. The limited amount of material processed to date appears to be completely free of copper pickup.

Support welding was down the major portion of the month due to the lack of supports .

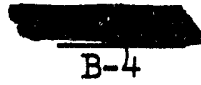


All three braze stations have been modified to give a more rigid chamber alignment. Braze was down 15 hours for vacuum trouble and 60 hours due to instrument trouble.

Six new length standards were made for the cutoff saw. These, with new spacers for cutting short elements, helped to increase saw throughput and reduced the chances of cutting elements to the wrong length.

Fifteen elements were rejected at the squaring lathe because they had been cut on an angle at the cutoff saw. Although is was impossible to reproduce the angle cuts in subsequent testing, the squareness is now being checked routinely.

Chemical milling was delayed on three separate occasions due to difficulties in pumping spent acid to recovery in 313 Building. Each time the storage facilities were full, thereby making it necessary to wait until they could accommodate the spent acid from 333 Building. Advance scheduling did not improve the situation.

A false alarm was given by the Critical Incident Alarm on December 8, 1962. Fortunately it occurred on the weekend when material was not being processed. The alarm was found to have been caused by a faulty photomultiplier tube. The tube was replaced and a study is continuing to improve the system and eliminate alarms caused by system failure. 


\section{N.FUEL PRODUCT ENGINEERING}

Fuel Element Testing

\section{KER Loop Testing}

Loop 1 - A decontamination test is being run in Loop 1 . It is scheduled for completion by January 15, 1963, and a "crud" test is tentatively scheduled after the decontamination test. However, one of the four candidate thermocouple elements which HLO has fabricated for use in the "crud" test failed due to faulty thermocouple sheathing. This failure casts doubt on the advisability of charging any of these elements. If the "crud" test is not charged, twelve $\mathrm{KSE}-5$ elements will be substituted.

Loop 2 - The "tapered end closure" test which was charged on 11/26/62 Is operating satisfactorily and has accumulated approximately 420 MWD/T exposure. Goal exposure is $2500 \mathrm{MWD} / \mathrm{T}$ which should be reached during April, 1963. This test consists of ten NIE fuels with "V" shaped end recesses and mating caps, half of which are unbonded while the other half are Be-zr brazed.

Loop 3 - This loop is still shut down for pump repairs. It is expected that the loop will be returned to service during January, 1963. At that time it will be charged with 14 prototypic N-Reactor (NAE-1) fuel assemblies.

Ioop 4 - The fourteen NAE-1 fuel assemblies in Loop 4 are operating sacisfactorily and have reached an accumulated exposure of approximately $600 \mathrm{MWD}$ iT. Goal exposure is $2100 \mathrm{MWD} / \mathrm{T}$ and is expected to be reached about June $1,1963$.

Test Fuel Fabrication

NAE..1 Test Fuels

A charge of Fourceen NABwl fuels is on the shelf at the Krast Reactor ready for charging. These are backup charges for Loops 3 and 4.

Heacer Fuels For "Crud" Test

Ten sevenceen inch NIE-1 fuels with shroud tubes are available for use as heater elements with the "crud" test.

KSE-5 Test

One, thirteen element charge of KSE-5 fuel elements is complete and available for charging. An additional charge has been processed up to autoclaving and should be completed by January 9, 1963.
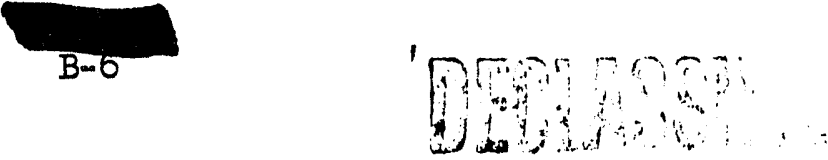


\section{$2 \% \mathrm{Zr}-\mathrm{U}$ Alloy NIN Test}

This test is for the purpose of studying the behaviour of uranium ailoyed with $2 \mathrm{w} / \mathrm{o}$ zirconium. Fuels for this test are currently at brazing and expected completion date is February 1, 1963.

The end recessing of this material was successfully accomplished using the combined processes of machining and air oxidation as described in the November monthly report.

Pilot Plant Schedule

The Pilot Plant PWR sumnary is shown on the following page.

\section{Materials Development}

\section{Ingot Concentricity}

Concentricity of all characteristics is a critical quality attribute of ccextruded fuels. Dimensional stability under irradiation, resistance to warp, and clad uniformity are all related in some degree to the concentricity of physical and metallurgical properties of the uranium.

This concentricity starts with a cast ingot and must be maintained through the primary extrusion operation. The ingot must enter the extrusion die uniformly. This cannot occur if the I.D. and O.D. are eccentric to each other, if the lead end of the ingot is not square or if the $0 . D$. surfaces are not a smooth cylinder. One 9 -ingot test has al ready shown that squaring and chamfering the lead end of the ingot will cause a very significant reduction in warp of the primary extrusion. This reduction in warp results in corcentric removal of metal in finish machining, in a higher billet yield, and in a more uniform billet. This reduction in warp and eccentricity was achieved because the chamfer caused the lead end of the ingot to lift on the die cone angle, centering the ingot in the container just prior to upset.

Further gains may be possible through machining of the $0 . D$. surface of the ingot concentric with the I.D. The smoother surface and improved concenticity of the ingot should result in a sitsighter and less eccentric primary extrusion with improved surfaces. After adequate testing, this siould permit the uae of a smaller extruszon die and less metai removal during final billet machining.

A specific feed site test has been designed to evaluate these gains. This test will involve processing of up to 36 ingots that have been end faced and chamfered. In addition, six solid cast and drilled ingots will be machined on the O.D. until concentric, end faced and chamfered. This group of six ingots will be used to determine the effect of using truly cylindrical ingots for primary extrusions.
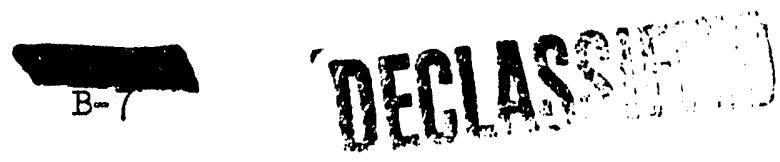
O PWR DATE

$\frac{\text { O⿱口口) }}{40 .} \frac{\text { ISSUED }}{9 / 10 / 62} \frac{\text { SPONSOR }}{\text { wK Alexander }}$

$489 / 18 / 62$ JL Guthrie

$49 \quad 10 / 1 / 62$ JL Guthrie

$5010 / 15 / 62$ WG Hudson

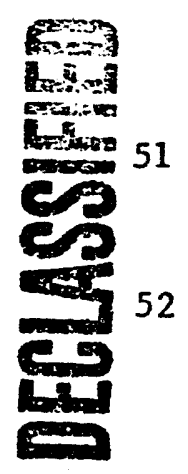

12/20/62 WK Alexander

$12 / 20 / 62 \mathrm{RK}$ Robinson
WORK DESCRIPTION

Determine if brazing alloy made with zirconium is superior to the current zircaloy base material.

Fabricate $1.6 \%$ enriched KSE-5 fuel $13 \mathrm{KSE}-5 . .12^{\mathrm{n}}$ elements for loop testing

Fabricate U-2 W/O $\mathrm{Zr}$ alloy fuel elements for KER loop testing to determine the effects of irradiation on swelling

Fabricate normal uranium companion $6 \mathrm{Nmj} \cdot 18^{\prime \prime}$ pieces for $\mathrm{U}-2 \mathrm{~W} / \mathrm{O} \mathrm{Zr}$ alloy loop charge.

Determine corrosion characteristics 6 IIIE and of white weld beads covered by cathodic etch removal of the autoclave film. Determine the effect of an extended autoclave cycle on fuels previously autoclaved for a nomal production cycle.

Evaluate the integrity of the cap- 1,000 closures clad braze below the wide braze groove

Provide fuel element assemblies $108 \mathrm{NAE}-24^{\prime \prime}$ for II-Charge Ilachine Test No. 22, 24 NAE-18" Part A
$13 \mathrm{KSE}-5-12^{\prime \prime}$ 4 INOE

IAATERIAL LOCATIOH

III PROCESS

Final Evaluation

"1

"I

DATE

Complete

is

$13 \mathrm{KSE}-5$ shipped to $\mathrm{K}$-Area Autoclave-25 KSE-5

10 Nmi-Brazing

20 IIrroBrazing

$2 / 1 / 62$

Final Evaluation

Complete

Summary to be issued

Not started

$4 / 163$

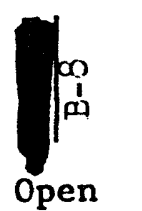

144 NAE.-Support Weld $30 \mathrm{WAE}$-Cut to Length

$2 / 11 / 63$

Open

28 NAE-Support Weld

35 NIE-Cut to Length

85 IOE-Chem. Mill

2 IAE-Final Heasure.

PWR

Summary

to be

issued

"

Open

"

:

चु 11

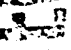

$x$

108 NAE $-12^{\prime \prime}$

2 IIAE-2L"I

$2 / 1 / 63$

Open
Evaluate the effects of loop vi brations on the performance of the fuel elenent supported under high temperature dynamic water conditions. 


\section{Coextrusion Process}

The following Engineering extrusions were made during the reporting month:

7.5 Inch Tooling

Three Zircaloy B1llets - Z-153, ZT-25, and ZT-26

z-153 - $2.9 \times 1.8$ zircaloy-3 tube for HLO

ZT-25 \& ZT-26 - 45-50 mil tubing for support fabrication

\subsection{Inch Tooling}

One Zircaloy Billet - z-152

Z-152

- 3/4 x 3-3/4 inch zircaloy flat bar

C-111

- Copper test estrusion for 2-152

Inner Tube - I.D. Bonding

A problem of bonding on NIE extrusions was encountejed on material extruded during late Hovember. The only known process variable coincident with this problem was the introduction of the square-ended billet design. Development testing has shown some indication that uranium billet geumetry (conicalend vs: square erf) has an effect on bonding due to differences in extrusion flow characteristics or reaction to chemical cleaning processes. However, past experience with both NIE and NOE billet designs using squareended uranium billets has not shown a billet geometry effect on coextrusion bond quality.

The general characteristics of this bonding problem differ from problems in the past in that: (1) the coextruded clad:core interface is relatively free from contamination (oxides, nitrides, etc.), (2) there is no apparent loss of billet vacuurn during the preheat cycle, and ( 3 ) many ( 40 to $50 \%$ ) of the extrusions lost have had 6 to 8 inches of "good" I.D. bond at both the front and rear of the extrusion.

Derrelopment extrusions and tests to isolate the exact cause, or causes, for this problem have not been successful to date. Further tests are now being designed in an attempt to isolate and eliminate, where possible, potential causes of the problem which include (1) billet geometry effect (mechanical or chemical), (2) billet cleaning process, (3) billet evacuation, and (4) differences in uranium or zircaloy components. These tests should be performed during the first week of January. 


\section{Chemical Processing}

\section{Rework Process}

The standard rework process for salvaging fuels with one reject end closure calls for cutting off the reject end closure and reprocessing of the fuel, beginning at chemical milling. Initial production with th is process resulted in severe pitting of the end closure exposed to reprocessing.

Pilot plant tests were initiated, based on the above experiences, and these tests showed that: (1) the pitting is caused by localized attack on the end closure weld by the chemical milling solution, and (2) the welds can be protected during chemical milling by coating with Amercoat No. 33 acid resistant paint.

A small number of test fuels were processed through the production facility with the above described coating. These fuels were examined following chemical milling and no evidence of end closure weld pitting was found.

Fursher test work will be performed in this area to insure maintenance of reprocessed end closure quality and to improve the techniques used for weld protection during chemical milling.

\section{Cleaning Autoclaved Zircaloy}

The most common contaminants on autoclaved fuel elements currently in final storage in the 333 Building production facility are shop dirt and fingerprints. Before releasing these fuel elements for final reactor storage, the surface contamination mast be removed and the elements protected from further contamination. Several cleaning techniques are being evaluated, including vapor degreasing, steam cleaning, alkaline soak cleaning, and organic solvent cileaning.

Preliminary results indicate that vapor degreasing tends to dissolve the oils from the fingerprints leaving an insoluble residue that is difficult to remove. Steam cleaning without detergent and alkaline soak cleaning both appear to perform satisfactorily. Soak or spray cleaning in high puriry acetone or echanol has been used efficiently in the laboratory for the cleaning of aucoclaved zircaloy coupons prior to reautoclaving. llowever. the safety preciancions required in using these flamabie solvents reduces their suirabilicy for a production cleaning process.

\section{Uranium Billet Etching}

A cursory examination of uranium billet etching in nitric acid was made this month to determine the effect.(s) of billet geometry and etching techniques on etch rates. Two square ended NIE billets, 6 inches and 20 inches long, and one pre-shaped NOE billet, 6 inches long, were given several nitric acid etching treatments and their change in I.D. measured. The results are summarized as follows:
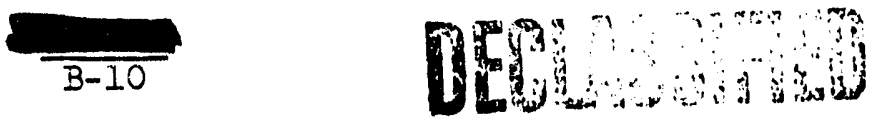
1. The standard billet etching process removed approximately one mil from the I.D. of all three billets.

2. Plugging the bore at the bottom and then processing the billets according to the standard technique (Step 1) also removed approximately one mil froia the I.D.

3. Wire brushing the bore of the 6 inch NIE billet while in the nitric acid pickle, but otherwise processing the same as in Step 1, resulted in approximately $0.5 \mathrm{mil}$ removal from the $I . D$.

It has been postulated that the etch rate of uranium is dependent upon the nitrous acid concentration rather than the nitric acid concentration. Thus, increasing the contact of fresh acid, as by wire r...nhing, might retard the etching process while plugging the bore should increase the etch rate. These effects were not completely evidenced by the few runs made; however, there was a noticeable reduction in the amount of metal removed from the I.D. of the billet that was wire brushed.

More complete studies of the billet etching processes are being initiated including anodic etching and organic drying.

\section{Autoclave Process}

\section{Inspecring For White Oxide}

The ability to detect light gray or white stains on autoclaved fuel elements is sometimes reduced because of the highly reflective nature of the autoclave film. Reducing the reflected light by placing the fuel element in a dark container tends to reduce the inspectability of the 11ghter stains. However, by using a polarized light source and viewing the fuel element through polarized lenses, the white and gray oxides become more pronounced while the reflected light from the glossy black film is almost eliminated. Also, dust particles and other contaminants on the surface of the fuel element tenc to show up more clearly using polarized light.

End Closure Development

\section{Beryli ium-Zircontum Brazing Alloy Tests}

Twelve each NOE and NIE fuel pleces were brazed using alloy made with zirconium zather chan zircaloy. It had been sugesed that such alloy might be less expensive and aiso might háve a slightly lower melting point and better wetting characteristics. Ali forty-eight closures made were judged to be good in that no rejects were found when put through the regular nondestructive tests. No significant differences were decernable during the brazing operation, although no precise melting point or wettability tests were run. The weld beads produced by the standard TIG welding process appeared to be appreciably more uniform than normal.

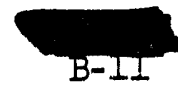


After autoclaving in $400^{\circ} \mathrm{C}$ steam for 72 hours, the weld beads were unusually dark and uniform. As a further corrosion test, about half of the specimens were further autoclaved in $360^{\circ} \mathrm{C}$ water for approximately 300 hours. They retained their good appearance during this final test.

On the basis of these tests, it is concluded that zirconium may be used in place of zircaloy in the fabrication of brazing alloy.

\section{Thin Braze Line Closures}

During initial development of the welding process for the brazed closure, it was concluded that it is necessary to have a braze line at least 20 mils wide to avoid hot-short cracking of the weld bead. Apparently a braze line of $20 \mathrm{mils}$ or more will supply sufficient beryllium to the weld bead to result in a zirconium-beryllium eutectic matrix which will contain the primary zirconium dendrites as they form, on cooling, without crasking. If less of the eutectic is present, the dendrites pull apart on cooling with restiltant cracks. To guarantee that sufficient braze alloy is always available, to prevent weld cracking, it is necessary to machine a groove in the cap so that when the cap is faced off a wide braze line will be exposed.

More recent developments have indicated that weld cracking will not occur, even with a narrow ( $<20 \mathrm{mils}$ ) braze line if the welding technique is changed to minimize mixing of the braze alloy in the weld. To accomplish this, the end of the fuel element is faced flat, with no step cut, and the weld is run just to the side of the braze line. Since the braze alloy melts at abour $1000^{\circ} \mathrm{C}$ lower temperature than the zircaloy cap, it is possible tc, melt and recast the braze line to a depth of approximately 50 mils without significant mixing of the braze alloy and the weld bead. This melting and "chill" recasting of the braze eliminates any porosity in the braze line, which is the object of welding. Optimum welding techniques to achieve this goal are under development.

\section{Thermal-Cycle Testing of the Braze Closure}

Dimensional Inscability

Inner-ube samples that were cycled 45 times through the temperature range $20^{\circ}$ to $730^{\circ} \mathrm{C}$ showed large dimensional changes. Using a temperature range of $225^{\circ}$ to $450^{\circ} \mathrm{C}$ to approximace the temperature range of the $N$-reactor, dimensional changes of not more than 1 mil were found in an inner and outer tube sample after 30 cycles. These tests confirm the stability exhibited by $\mathrm{N}$-fuel elements in the KER-reactor loop testing program and indicate that bi-metallic thermal growth should not be a problem. 
Resistance of Cap:Core Bonds to Thermal Cycling

Temperature Range of $20^{\circ}$ to $730^{\circ} \mathrm{C}$

N. Inner Tube Samples

The endurance limit of the braze closure to thermal cycles in the temperature range of $20^{\circ}$ to $730^{\circ} \mathrm{C}$ is in excess of 21 cycles. For 27 aamples that have been thermally-cycled, the limit may be expressed by the following examples:

One cap:core unbond after 4 to 9 cycles. Five failures after 22 to 45 cycles. Three failures after 46 to 48 cycles. Three samples have not failed after 54 cycles. Nine samples have not failed after 27 cycles. Three samples are possible cap:core unbonds after 27 cycles.

Three samples have not failed after 3 cycles.

A fallure is defined as a separation of the cap:core plus fallure of the inner clad.

The sample that is shown as a cap:core unbond after 4 to 9 cycles should be considered as having incurred only the first stage of a 2-stage failure mechanism. This closure was sectioned and examined metallographically. The examination disclosed an unbond extending over 300 degrees of the circumference and the unbond was associated with areas where no intermetallic compound had formed between the braze metal and the uranium core. There was no evidence of shear in the clads in the plane of the unbond. Rather, the inner clad showed very smail cracks that appeared to be from tensile stress rather chan shear stress.

Generally, the dara show that a fallure of the inner clad will occur soon after the cap-cowcore bond fails. The mean value of the endurarce limit is expected to be found in the range of 45 to 55 cycles.

IN-Outer Tube Samples

The endurance limit of the braze closure to thermal cycles in the temperature range of $20^{\circ}$ to $730^{\circ} \mathrm{C}$ is in excess of 21 cycles. Three samples have shown possible cap-to-core unbonds after 21 cycles. Nine samples show no damage after 12 cycles.

The mean value of the endurance 1 imit cannot yet be approximated. 


\section{Temperature Range of $70^{\circ}$ to $450^{\circ} \mathrm{C}$}

N.. Inner Tube Samples

Three samples show no damage after 21 cycles.

N-Outer Tube Samples

Three samples show no damage after 21 cycles.

\section{Interpretation of Nondestructive Testing Data}

A soundly-brazed sample will sometimes show an echo (1.e., reflection) of the transmitted ultrasound from the braze metal:uranium interface. Two samples showing different reflection intensities from this interface have been examined metallographically and were shown to have intermetallic compound formation inversely proportional to the reflection incensity. It is tentatively concluded that interfaces without compound formation reflect the ultrasound from mechanically-bonded interfaces.

A separate study of nondestructive testing data versus the nature of the compound layer has been given priority over the thermal cycling work in the temperature range of $70^{\circ} \mathrm{C}$ to $450^{\circ} \mathrm{C}$. Impetus to this work was also added from the metallographic examination of the sample that showed 300 degrees of unbond after nine thermal cycles; this sample showed no compound formation in the area of the unbond.

\section{Gas Pressure Bonded End Closures}

Lot No. VII

This lot had titanium closure rings, 0.100 inches thick, for studying the filling of the sriations on the inside of the cladding. The first specirnen failed in $360^{\circ} \mathrm{C}\left(680^{\circ} \mathrm{F}\right)$ water in 98 days. From what has been learned recently of.the scriation problem, it appears that this failure was due to an incompletely filled striation. The remaining three specimens are continuing in the water autoclave and have an elapsed time of three days in steam plus 151 days in water. The zircaloy-2 cladding has lost its black lustrous finish and is a very dark gray approaching a black color. The titanium has lost 1ts silvery metalic lisstre and is tuming a dark gray approaching a black color.

Lot No. XI

In order to try to eliminate the pipes produced by the residual cladding striations after gas pressure bonding at $10,000 \mathrm{PSI}, 650^{\circ} \mathrm{C}\left(1202^{\circ} \mathrm{F}\right)$, for one hour at temperature, using zirconium closure rings with smooth

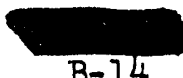


bonding surfaces, closure rings with semi-circular ridges circumferentially around the bonding surfaces were tried. Exposure of 3 NOT and $4 \mathrm{NIT}$ specimens in $400^{\circ} \mathrm{C}\left(752^{\circ} \mathrm{F}\right)$ steam for 50 days has not produced a failure. Corrosion of the zirconium closure rings varied from negligible to white corrosion that was peeling. One specimen had excessively heavy breakaway corrosion and has been removed. Exposure of $3 \mathrm{HOT}$ and 4 NIT specimens in steam for 3 days plus 53 days in $360^{\circ} \mathrm{C}$ $\left(680^{\circ} \mathrm{F}\right)$ water has produced no failures. The surfaces of the zirconium closure rings have a lustrous black to dark gray approaching black. The only evidence of white corrosion is on the inner bond line of one NIT specimen. It was observed after steam autoclaving and has shown no change in magnitude.

\section{Lot IIo, XIII}

This lot, using zirconium closure rings with smooth bonding surfaces, was produced to determine if gas pressure bonding at 15,000 PSI, $\left(650^{\circ} \mathrm{C}-1202^{\circ} \mathrm{F}\right)$ for one hour at temperature would eliminate the pipes, produced by the striations on the inside of the cladding, not filling during the bonding cycle. Steam autoclaving at $400^{\circ} \mathrm{C}\left(752^{\circ} \mathrm{F}\right)$ for 72 hours produced one incipient failure at the closure ring-cladding-core interface about $1 / 16$ inch in diameter.

Lot Ilo. XVI

This lot was prepared by the standard $\mathrm{Be}-\mathrm{Zr}$ braze process without closure welds to determine the long-term effect of $360^{\circ} \mathrm{C}\left(680^{\circ} \mathrm{F}\right)$ water and $400^{\circ} \mathrm{C}\left(752^{\circ} \mathrm{F}\right)$ steam on brazed joints. Previous to shipping, they were exposed to $400^{\circ} \mathrm{C}\left(752^{\circ} \mathrm{F}\right)$ steam for 72 hours with no evidence of failure or corrosion. At the end of 30 days, $12 / 27 / 62$, there was no evidence of ailure or white corrosion. It is planned to run the test for six months or until failure occurs.

\section{Titanium-zirconium Alloys}

In view of the excellent diffusing properties of titanium, alloys of $6,8,10$, and $12 \mathrm{w} / 0$ titanium-zirconium have been prepared and autoclaved in steam at $400^{\circ} \mathrm{C}\left(752^{\circ} \mathrm{F}\right)$ for two weeks. The corrosion rate vas in excess of anything experienced with zirconium. According to Lustman and Kerze, "Netallurgy of Zirconium", these alloys should have had good corrosion resistance. Another group of the same alloys plus 25,50 , and $75 \mathrm{w} / 0$ titaniummirconium are being prepared to repeat the experiment. In addition, specimens of the same composition will be autoclaved in $360^{\circ} \mathrm{C}\left(680^{\circ} \mathrm{F}\right)$ water.

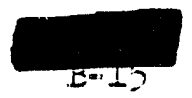




\section{Fuel Element Supporis}

\section{Design and Procurement}

As was stated in last month's report, the outer support design for the Nofuel element was changed from the "suitcase handle" to the "arch" design. The purpose was to increase.the impact and crushing strengths of the outer support. The earlier "suitcase handle" design appears to have adequate properties insofar as.in-reactor performance is concerned, but the problem of preventing damage from the time of manufacture until the time of placement in the reactor is of some concern. Therefore, while some of the "suitcase handle" type design outer supports will be used, it is planned to convert to the "arch" type as soon as possible.

The design of both inner and outer supports has not changed since last month $s$ report, and major activity has been in actually fabricating strip and forming supports. A source of adequately ducrile strip has not yet been established, and HLO is currently rolling strip from split cladding shells. This material has crystallographic crientation characteristics such that it has adequate bend ductility to make either support. The specific aim of the program is to have adequate inner and outar supports so that production can be under way on both of the se items prior to February 1. In sumary, the major points of the support program are as follows:

1. Up to 5,000 outer fuel elements will be fabricated with "suitcase handle" oliter supports from stocks now on hand at HAPO.

2. The "arch" type support will be procured initially by on-site fabrication. The rooling for tinis support has been completed and is now being debugged. HLO is rolling strip from cladding shells and will be able to supply this operation. Until industrial procurement of this part can become an accomplished fast, on site fabrication will be conrinuea.

3. Inner supports (buggy springe) are now being fabricated on-site from HLO produced Exrip. There are some minor details of the tooling to te corrected before these supports will meet specifications. However, ir is expected that these correcrions will be made shortly and adequate supplies of inner supports will be made locally until offisite procuremenc can be estabizished.

4. Is is planned to procure addicional quantities of both inner and outer supports as soon as possibie, through normal industrial procurement, by disclosing the strip fabrication technology to potential suppliers. However, because of classification and clearance problems and the fact that the orders are hardly large enough to justify "rush" action, it is improbable that industrially supplied parts will be available before May 1, 1963.

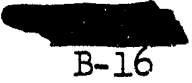


5. Development forming and strip fabrication evaluation is being carried sut on a DDR contract with an industrial shop in Portland. This activity has produced both good strip and good supports. With more proof checking, it is quite possible that this combination will be making good supports during January. If this situation develops, contractual problems will be the main hindrance to procuring supports from off-site.

\section{Weilding Process}

Some concern developed during the month on the effect of slight burns on one or both ends of some outer tube supports. These burns are caused by a downward slope of the support feet which impede the embossment during the final stages of the weld cycle. Although a reduction in weld strength can occur due to this burning, numerous destructive tests have not indicated any significant decrease in weld strength.

The only problem created by the above burning is that small white spots are formed on the burned portion of the outer tube supports during autoclaving. To provide a cleaner surface for final etching and thus eliminate the white oxide during autoclaving, the burned supports were brushed lightly with a motor driven steel brush. Autoclaving experience on material so brushed has shown no further difficulty in this area.

\section{Equipment Deveiopment}

\section{Projects Completed}

\section{Shoe Forming Die - Hand Operated}

The hand operated shoe forming die was designed and fabricated for use until the production unit is available.

\section{Crimping Tool For Altaching Shoes}

The crimping tool for attaching shoes is complete but needs some hand finish work. The latter will be done when some sized supports on the fuel tubes are available.

\section{Outer Support Blanking Die}

The die for blanking out supports is complete. This was an interim tool to be used until tLO receives the proper sheet slitting cutters.

Outer Support Forming Die

The outer support forming die is complete and is installed on a new mechanical press in the 306 Pilot Plant. Equipment debugging should be complete by January 4, 196\%. 


\section{Outer Support Sizing Machine}

The outer support sizing machine is fabricated and is installed in 306 Pilot Plant. Final testing of the sizing machine should be complete by January 4, 1963.

Clean Room - 333 Building

The decision was made to set up a semi-clean room using chains and curtain walis of plastic and painting the area white. A filter was installed on the supply air outlet to check for gross quantities of dirt particles. After 48 hours, the filter was removed and no particles were detected. Another check will be made later if deemed necessary. No further work will be done on improving the "clean room" unless requasted.

\section{Projects in Progress}

Inner Support Sizing Tool

The inner support sizing tool is being modified. The tool should be complete by the end of December at which time it will be turned over to sLO since they have the inner support development program.

\section{Shoe Fabrication and Forming Tooling}

The shoe fabrication and forming tools are being fabricated. The tooling will be available to start debugging by January $7,1963$.

Dowel Wrapper - Autoradiograph

The dowel wrapper is used to wrap $16 \mathrm{~m} . \mathrm{m}$. film around dowel rods for radiographing the bores of inner fuel tubes. A new device was fabricated and installed. The first testing indicated that problems still exist in wrapping the film uniformly without spaces or overlaps. If this simple device cannot be made to work, and a fool-proof mechanism is required, it may cost $\$ 10,000$ to $\$ 20,000$ to design and fabricate a machine which will meet the requirements. 


\section{N Fuel Testing}

Post extrusion tests to determine inner clad variation have been performed on three extrusions. Correlation with the new radial ultrasonic test - B test - on the billets, before extrusion, shows promise but the sample size is too small for definite conclusions. Investigation has started on using an eddy current test to examine the inner bore of billets for correlation with extrusion results. The first trial probe was unsuccessful due to lack of sensitivity and another is being developed.

The routine operation of fuel testers has continued to be plagued by downtime. The welder interference problem has been reduced by bullding grounding and the purchase of spare parts for critical equipment will reduce downtlme. The new lightweight outside probe using neoprene wear surfaces is undergoing laboratory life tests and looks promising after two weeks continuous testing.

Evaluation of the ultrasonic grain size, or attenuation, test on NIT elements for correlation with warp and heat treatment has been completed. No correlation of warp with either grain size or variation in grain size was observed. Positive correlation of grain size results with heat treatment was observed on all samples. After heat treatment the grain size was increased as well as improving the uniformity. This test would allow a check of heat treatment not now available. A similar test for NOT elements is being investigated; geometry differences complicate this test.

Alsi Fuel Testing

Availability of 313 Building testers was down about five percent from the previous month. Testing Methods control of equipment operations and maintenance has been reduced by the recent reorganization. Auditing has continued but correction of problems has proved more difficult.

Completion of laboratory tests on bond test variables and analysis of the data have resulted in a clearer insight into present problems. Development of the second generation tester will rely on these results as a guide to a reproducible production test.

An investigation into differentiating between fine grain beta transformed cores and partially untransformed cores was instigated due to the refinement of grain size in the recent months. It was found that UT-2 testing was adequate for detecting this material without objectionable reject rates on fine grain material by changing standards at National Lead Company of Ohio. This has been done. Considerable safety factor in this separation remains if the testers are operated properly.
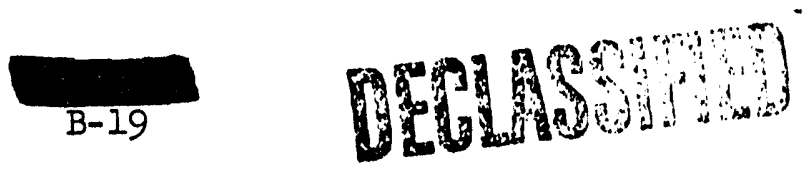
Irradiated Fuel Testing Facilities

HW-76050

\section{DECLASSPFing}

Reproducibility on the AISi test equipment at 105-C has been improved considerably by modifications and it is now ready for irradiated element testing. Electrical noise problems have been minimized to the point that the tests can be performed, and may not need further investigation. The equipment for $N$ element testing has been undergoing several time-consuming mechanical modifications which have delayed checkout of the system.

\section{General}

Several tests were applied to the problem of Ceramic Fuels, HLO, fuel element uniformity. The plutonium distribution in the element needs to be determined quickly and nondestructively. Ultrasonic and eddy current tests did not appear promising but use of the gamma analyzer was quite successful. Preliminary tests showed even small (I/4") bands of heavy plutonium concentration were measureable. This method looks favorable for actual determination of quantity measurement of plutonium. A proposal for such a test was made.

Toroidal coil usage for detection of radial cracks in rod or tubing is being investigated. It was demonstrated that this technique is much more sensitive to this type defect than the common encircling coil type.

Specifications have been written for the boroscope camera for examination of $N$ fuels inside bore and the AR approval is all that is needed for bid requests.

The enrichment detector for 313 Building has been checked out and standards checks were within one percent. A test of fifty assorted fuel elements was conducted and revealed an interesting anomaly. Cores from one ingot exhibited much higher count than expected. This was traced by investigation and use of a 256 channel analyzer to isotropic ruthenium in some of the cores. This problem is still being investigated and use of the equipment will be delayed until it is resolved.

The prototype tester for plutonium testing is on schedule and tank fabrication is complete. A rough draft of the UT-4 engineering report has been finished.

Metallographic and gas analysis of all zirconium hydride process tubes has been completed. Hydride samples were all lower than calculated values. Samples testing as low as $300 \mathrm{ppm}$ hydrogen have been observed ultrasonically. A beta grain region was found in the hydride regions on the 500 and $1500 \mathrm{ppm}$ samples. By 10:alized heat treatment, samples of beta grain were fabricated on hydridefree sample tubes. This grain size does affect the signals significantly and would be another variable in the hydride detection problem. The other in varlable is wall thickness.

LM Loeb:vb

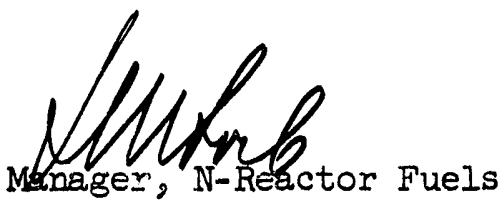


RESEARCH AND ENGINEERING

\section{DECEMBER 1962}

TRIPS

Name

E. D. Sayre

R. W. Benollel

R. W. Benoliel

R. E. Hall

J. T. Long
Compeny

GE-MSD

Philadelphia

GE-Research Lab

Schenectady

GE-MSD

Valley Forge, $\mathrm{Pa}$.

Burns \& Roe

Hempstead, N. Y.

Consolidated Edison Co. Buchanan, N. $Y$.

\section{Contact}

Date Reason

J. Lommel

$12 / 4$

J. Gebhardt

$12 / 10$

E. T. Lewis $12 / 10$
$12 / 13$

R. Freyberg

M. Smith

D. McCormick
$12 / 11-$ $12 / 20$
Technical

Recruiting

Attendance at Tech. Conference on pryolytic graphite

Tech. discussions on pyrolytic graphite

Discuss design concepts \& details of NPR heat dissipation system

Review startup procedures of Indian Point Nuclear Power Plant.

PERSONNEL

Additions (Includes only those persons added after December 1 establishment of the N-Reactor Department.)

Name

I. D. Smith (Tech.Grad.)

M. A. Murphy (Technician)

Betty W. Howard (Secretary E)

Mary L. DeMeyer (Steno Typist

\section{From}

HI

New Hire

New Hire

CE\&UO
To

Process Evaluation \& Control

Process Evaluation \& Control

Process Evaluation \& Control

Process Evaluation \& Control
Date

$12-3-62$

$12-3-62$

$$
12-17-62
$$

$12-21-62$ 
Removals

None

Total Personnel
December 1

21

3

24
December 31

21

$\underline{6}$

27

INVENTIONS

All Research and Englneering personnel engaged in work that might reasonably be expected to resilt in inventions or discoveries advise that to the best of their knowledge and belief, no inventions or discoveries were made in the course of their work during December, 1962. Such persons further advise that for the period therein covered by this report, notebook records, if any, kept in the course of their work have been examined for possible inventions or discoveries.

\section{SIGNIFICANT REPORTS ISSUED}

HW-71408, "NPR Hazards Review, Volume 2," N. R. Miller and R. E. Trumble, December 1,1962 (Secret).

Letter, "Acceptable Response Time for Resistance Temperature Detectors for NPR Process Tube Temperature Monitoring," K. W. Norwood to R. E. Trumble, December 26, 1962 (Unclassified).

HW -75645 , Pt. IP.551-A, "KER Cleaning and Startup," W. K. Kratzer and M. J.Wise (IPD), December 1,1962 (Unclassified)。

\section{SECURITY VIOLATIONS}

None

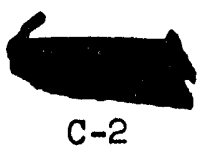




\section{ADVANCED TECHNOLOGY}

\section{Technical Planning System}

A new $\mathrm{N}$ - Reactor Department Technical planning system has been developed and reviewed by Management. It will be put in place in time for detailed 1963 Technical planning. This plan also provides for inclusion of the Department in the PERT system in the near future.

\section{REACTOR ENGINEERING}

\section{NPR Production and Cost Studies}

The study being performed in concert with the Advanced Technology Operation, of NPR production and cost projections for the ten year period 1963 to 1972 , is progressing on schedule but is still incomplete. Included to date are studies of four fuel concepts. The studies indicate the N-Reactor to be capable of economic production of plutonium, power and several isotopes, including neptunium-237. Studies of tritium production are still ircomplete.

Thermal Hydraulic Research Program

A program proposal to acquire data on NPR connector and plugged fuel element flow and pressure drop characteristics in the Test Facility in 189-D has been drawn up. The data will be used to assist in proper execution of the nain. Investigation of tube plugging and heated flow to be performed by Thermal Hydraulics (HL).

\section{PROCESS EIALUATION AND CONTROL}

Nuclear Health and Safety

Volume 2 of the NPR Hazards Review, consisting of material supplemental to and supporting the summary hazards review, Volume 1, was issued on December 7 , 1962. No conclusions were altered; however, re-evaluation of experimental data indicated that the margin of safety in control rod strength, while still adequate, is slightly less than reported in Volume 1. Thirty-five copies of Volume 2 were released to ROO-AEC.

\section{NPR Design Participation}

Emergency Dump Bas in Design

The design concept and preliminary detail design for the Emergency Dump Basin was reviewed and accepted by the Project Representatives. This basin is a minimum cost facility which meets minimum operational requirements.

The following listed operating concepts, prepared by Burns and Roe, Inc., were reviewed and accepted for design by the General Electric Company Project Representatives:

\section{a. Emergency Seal Water Concept}

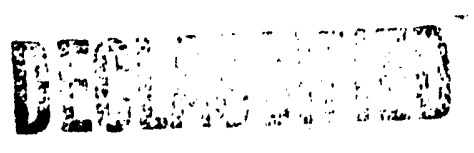




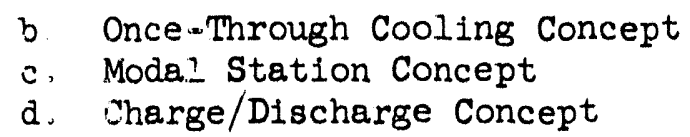

Water Quality Monitoring Equipment

The design specification for the Hot Water Quality Monitoring Laboratory was revised extensively by General Electric Company and has been tentatively approved in rough draft form by the Project Representatives. This concept reflects the change in responsibllity between General Electric and Burns and Roe, Inc., for this facility.

\section{CHEMISTRY AND METALLURGY}

Irradiation Testing in Support of $\mathrm{N}$ Reactor Fuel

$K E R=1$

KER-1 is empty. A test involving rusting and cleaning of the KER-I carbon steel piping, PT-IP-551-A, is planned prior to the first fuel charge. This test is intended to provide information to guide $\mathrm{N}$-Reactor primary piping pre-startup cleaning procedures. This test should be completed in January at which time the first fuel charge will be loaded.

KER $\cdots 2$

KER-2 was charged November 27, 1962, with eight 17-inch $\mathrm{N}$ inner tubes with bonded and unbonded contoured end closures under PT-IP-536-A, Supplement A. Th1s charge reached an exposure of $420 \mathrm{MWD} / \mathrm{T}$ on December 25, 1962. The test is planned for discharge during April, 1963, at an exposure of $2500 \mathrm{MWD} / \mathrm{T}$.

$\underline{K E R-3}$

KER 3 is out of service because of pump difficulties. A charge of fourteen $\mathrm{N}-\mathrm{fuel}$ elements with a downstream flow channel temperature measuring thermocouple train is available for loading when the loop is ready.

KER

The fourteen $\mathrm{N}$ elements charged into KER-4 on September 26, 1962, reached an $\equiv x p o s u r e$ of $620 \mathrm{MWD} / \mathrm{T}$ on December 25, 1962. This test is planned for a goal exposure of $2100 \mathrm{MWD} / \mathrm{T}$ which should be obtained during June, 1963.

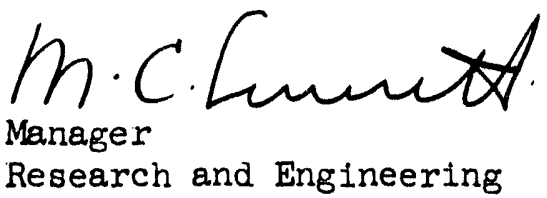

MC Leverettimlk

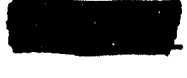




\section{N-REACTOR DEPARTMENT}

FINANCIAL OPERATION

DECEMBER, 1962

The principal activities of the Financial Operation during December, 1962 were directed toward organization and inftial operation of $\mathrm{N}$-Reactor Department. These activities included:

1. Writing and distributing interim procedures for essential forms and reports.

2. Allocation of funds on an equitable basis to N-Reactor Department.

3. Review of the funds allocated to $\mathrm{N}$-Reactor Department for adequacy.

4. Preparing or assisting in the preparation of forms, position guldes, and other work associated with the establishment and staffing of $\mathrm{N}$-Reactor Department.

5. Finalizing organizational codes and equipment codes for N-Reactor Department.

6. Assignment of work within the N-Reactor Department Flnanclal Operation.

Certain information with respect to $\mathrm{N}$-Reactor Department after one months operation follow:

\begin{tabular}{|c|c|}
\hline Exempt & 218 \\
\hline Nonexempt & 196 \\
\hline
\end{tabular}

Total salary payments

$\$ 323,965$

Total operating costs

$1,041,856$

Due to the custody takeover of certain 100-N Area buildings by General Electric Company on December 17, 1962, operating procedures w'are arranged with J. A. Jones Construction Company and Kaiser Engineers for the sccumulation and transfer of costs incurred to complete these facilities.

Procedures were also prepared and distributed for the control of costs to be incurred for the account of WPPSS.

Requisites for an essential material reporting and control system were discussed with personnel. of $\mathrm{N}$-Reactor Fuels, and $\mathrm{N}$-Reactor Plant Sections. The system to be used is presently being studied. 
Plans were formulated for 1ssuance of Department OPGs. The proposed OPG on delegations of routine authority has been prepared and issued for comments.

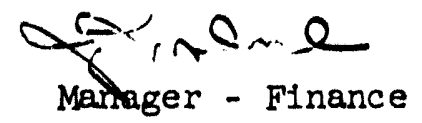

$J$ M1.lne:pw 
N-REACTOR PROTECT OPERATYON

\section{RESPONSIBIIITY}

There was no change of responsibility since last month's report. ORGANIZATION AND PERSONNEEL

\section{$11 / 30 / 62$}

88

$\underline{23}$

111

88
- Exerrpt

Non-Exempt

TOTAL N-REACTOR PROJECT PERSONNEL

Transfers

Name

Freed, GT

(Exempt)
From

Reactor Building \& Auxiliaries
To

N-Reactor Plant Operation
$12 / 31 / 62$

87

23

110

Effective Date

$12 / 1 / 62$

SAFETY AND SECURITY

No disabling infuries and no security violations were reported. TNVENTIONS OR DISCOVERIES

All persons engaged in work that might reasonably be expected to result in inventions or discoverles advise that, to the best of their knowledge and bellef, no inventions or discovertes were made in the course of their work during the period covered by this report. Such persons further advise that, f'or the perlod therein covered by this report, notebook records, if any, kept in the course cf their work have been examined for possible inventions or discoveries. 
N-REACTOR PROJECT

\section{TRIPS}

Name

Davis, HS

Davis, HS

Nesbitt, $\sqrt{F}$

Flickinger, $\mathrm{JK}$

Reinig, IP

Mundt, W.J

Sol1tis: $\mathrm{FD}$

D

\section{Firm and Location}

ANS Meeting

Washington,

D. C.

Burns and Roe, Inc. Hempstead, N. $I$.

Tacoms Boat Bullding

Trcoma, Washington

General Dynanias

Rochester, N. Y.

General glectric

Schenectady, N. Y. Chandler-Evans Corp. Hartford, Conn.

McCullough, JD

McCullough, JD

Rohrbacher, RA
Engelhard, Newark, N.J. 12-5-62

Avien, Inc.

Woodside, N. Y.

Western Piplng and

Englneering

San Francisco, Calif.

Burns and Roe, Inc. Hempstead, N. Y.

Travelers Insurance Co. 12-17-62 Seattle, Washington

and $12-27-62$

$12-6$ to $12-10-62$

12-10 to $12-11-62$

$12-10$ to $12-14-62$
$11-26$ to

$11-28-62$

$11-29-62$

$11-27-62$

12-1 to

$12-7-62$

$12-3$ to $12-2.1-62$

Consultation w:th Burns and Roe, Kalser Engineers and Travelers Insurance Co. regarding certifica tion of the 184-N boiler.

\section{VISITORS}

Iatham, $\mathrm{R}$.

Woodward, BE
Gray Tool Company Houston, Texas

FE - APED

San Jose, Jalifornia
$11-26$ and 11-27-62

12-19 and To discuss tests on Nuclear $12-20-62$
Consultation on Grayloc flange alignment and clean-up techniques

To discuss te
Flux Monttor. 


\section{N-KEA WTOR PROUETI OPERATION}

\section{SIGNLOALE REFORIS ISSUED}

\begin{tabular}{|c|c|c|c|c|}
\hline HW Numir ex & Iassiflcation & Author & Date & Itle \\
\hline $\mathrm{HW}-74291$ & Sonfidential & $\begin{array}{l}\text { Stepnewskt, ID } \\
\text { Goss, CI }\end{array}$ & $11-3 i-62$ & $\begin{array}{l}\text { Analysis in Support of the NPR } \\
\text { Confinement Concept - Interim } \\
\text { Report }\end{array}$ \\
\hline HW-?5ב35 & Un:Lassifled & Fastabend, JH & $12-31-62$ & $\begin{array}{l}\text { Zircaloy-2 to Carbon Steel } \\
\text { Expanded Ijint - Nweactor } \\
\text { Pro:ess Thube Fitting }\end{array}$ \\
\hline HW- 75589 & Secret & Agar, $\mathbb{D}$ & $12-25-62$ & $\begin{array}{l}\text { K-Reactor Retubing Program - } \\
\text { Graphite Temperature Study }\end{array}$ \\
\hline HW- 75646 & Unoiasalfied & $\begin{array}{l}\text { Lenkersdorfer, } \\
\text { HD }\end{array}$ & $12-i-62$ & $\begin{array}{l}\text { Tharging Machine Design Test } 2: \\
\text { Fue: Eiement Charglisg }\end{array}$ \\
\hline$H W-7565^{\prime} ?$ & Unvlassified & Goss, & $12-28-62$ & $\begin{array}{l}\text { Iogic for Rea:tor Safety } \\
\text { Jirouit Systems }\end{array}$ \\
\hline $\mathrm{HW}-75902$ & Secret & Dowis, We & $22-: 4-62$ & $\begin{array}{l}\text { Information for One-Month } \\
\text { Study, Multi-Produ:t } \\
\text { Oceration of NPR }\end{array}$ \\
\hline None & Unalaseffied & Love, WJ & $12-10-52$ & $\begin{array}{l}\text { Sontrol Rod Scram Deceleration } \\
\text { Sushion Porting }\end{array}$ \\
\hline
\end{tabular}




\section{N REACTOR PROJECT}

PROCESS DESIGN OPERATION

Process Research and Development

Calculations have been made to determine the thermal stresses occurring in the diversion system plping. Results show that the maximum stresses will not exceed the allowable stress range.

Data required for calibrating the primary and thermal shield cooling system instrumentation have been compiled and forwarded to the field.

A final report on a study of the consequences of an inlet riser rupture has been prepared. This report indicates that no fuel melting is expected following an inlet riser rupture if the emergency cooling system functions as designed.

Work has continued to develop an analog program for analysis of the High Pressure Injection System. All system equations have now been developed. Machine set-up on the Hanford Laboratories analog computer has been scheduled to start on January 7, 1963.

\section{Conversion}

In response to a request from the Atomic Energy Comission, an estimate was made of the cost to perform a topographic survey and river sounding in the area of the proposed electrical generating plant. An estimate of $\$ 9,760$, including General Electric general overheads, was provided.

A letter, dated December 14, 1962, from the Atomic Energy Commission authorizing a total expenditure of $\$ 25,000$ has been accepted by General Electric. of this amount $\$ 9,760$ was authorized for river and site topographical work. The baiance is provided to perfo-m engineering studies for Phase II operation. The letter also statis that the Atomic Energy Comission expects to authorize the balance of the $\$ 61,000$ before the end of December, 1962 .

Preliminary results of the engineering studies for Phase II operation were reviewed at December 20, 1962, meeting between representatives of the Atom1c Energy Commsion, R. W. Beck and Associates, Burns and Roe, BPA, and Genergl Eiestric.

Steam and condensate flow distribution in the secondary cooling system under possible Phase II conditions has been examined. The emergency cooling system is satisfactory for operation of the N-Reactor under six-loop Phase II conditions. However, cortrol instmumentation will have to be modifled as necessary to include a sixth pump.

Pressure transients and steam release rates from an inlet header rupture at Phase II and Phase III coolant conditions have been calculated. Steam 
vent requirements were then estimated for Phase II and Phase III. The results suggest that two roof-vent valves should be added for Phase II and six vent valtres should be added for Phase III. Further analysis of the best method to provide confinement venting from the sixth cell will be necessary.

\section{Project CAI-816}

\section{Hot Water Quality Iaboratory}

The specification and 31 drawings for the Hot Water Quality Laboratory equipment were revised to transfer design responsibility from Burns and Roe to General Electric and to effect a cost reduction estimated to be greater than $\$ 40,000$. The Atomic Bnergy Camission will procure this equipment on a CFFF basis and. has recelved proposals from Balley Meter Company, Beckman Instrument, and Tampa Bay Englneering.

Rupture Monitoring

Two of elght mupture monitor valve racks have been completed. The first rack was completed by HUICO on December 20, 1962, and shipped to the field where final hydrostatic testing and helium leak checking will be performed. The second rack was accepted by General Electric inspection and was shipped from Western Piping and Engineering on December 28, 1962.

Traveling Wire Flux Mapping

The specification for the Traveling Wire Flux Mapping system and one drawing were revised and an alteration to the purchase requisition was issued to Kaiser Engineers on December 27, 1962. The ievision shows a different shielding arrangement to provlde adequate personnel protection.

Process Tube Diversion Control Panel

One thousand and four switch block assemblies used in the Process Tube Diversion Control Panel have been modifled at General Dynamics. The modiflcations consisted of replacing 2,008 short screws and 2,008 thick washers to improve workmanship, to increase reliability, and to reduce fallures of a random, intermittent nature. On December 18, 1962, all switches were operated satisfactorily by a General Electric-HAPO inspector and the Process Tube Diversion Control Panel accepted.

Emergency Dump System

Designs for the minimum cost - limited life Bmergency Dump system were forwarded to Kaiser Engineers on December 14, 1962, before the promised date. The CPFF estimate is $\$ 195,000$ versus the goal of $\$ 250,000$.

The Dmergency Dump System is required to quench and contain the hot, radioactive contents of the primary loop in an emergency when the loop must be dumped and cooling changed from circulation to once-through. 


\section{Chemical Waste Storage}

The Jesign of the Chem1caI Waste Storage System, with one tank deleted, was forwarded to Kaiser Engineers on December 14, 1962, before the promised date. The followling costs were estimated:

\begin{tabular}{|c|c|c|c|}
\hline & Two Tanks & One Tank & Saving \\
\hline $\begin{array}{l}\text { Lump sum } \\
\text { CPFT }\end{array}$ & $\begin{array}{l}\$ 556,000 \\
\$ 650,000\end{array}$ & $\begin{array}{l}\$ 365,000 \\
\$ 415,000\end{array}$ & $\begin{array}{l}\$ 191,000 \\
\$ 235,000\end{array}$ \\
\hline
\end{tabular}

Flow Monitor Controllers

On December 5, 1962, Avien, the fabricator of the process tube flow monttor controllers, presented a study of cost-to-date plus cost-to-complete of $\$ 1,250,000, \$ 250,000$ above the negotiated fixed price, seeking financial reIlef. Avien representatives stated that only a small fraction could be considered to fa.ll in the claim area where they were asked to perform beyond the specification and contract conditions.

\section{Process Tube Diversion Valves}

Assembly of process tube diversion valves has been initiated by ChandlerEvans. Two valves were shlpped to Hanford on December 7, 1962. Production problems which have been encountered and resolved consist of body seal leakage, valve shaft leakage, valve shaft galling, setting of valve stops, erratic valve motion, and actuator air leakage. At month's end, the remaining problems consisted of production and quality control and the repair of approximately 150 outlet forging welds in whlch weld defects were detected.

Design Concepts - Heat Dissipation Plant

The Once-Through Design Concept was reviewed by General Flectric and acsepted on December 12, 1962, at Hempstead, New York.

Eor1zontal Rod Linkage

A life cycle tenston test of the horizontal rod drive to rod Inkage was completed on December 17, 1962. The IInkage, composed of production parts, was cycled 1,400 times between maximum tension force of 5,800 pounds and a minimum of 300 pounds. The differential force was twice the maximum force the linkage will be subjected to when installed and the number of cycles was twice the number estimated for the 25-year designed life. 


\section{FIEID ENGINETERING OPERATION}

Construction

105-N \& 109-N Buildings

Work on the general mechanical features in the 105-N Building under Subcontract SC-78 by Harder Industrial was completed December 1, 1962.

Kaiser Ingineers has continued the installation of ventilation duct work in the 105-N pipe spaces. Fifteen of the required 20 duct risers have now been installed and have passed the leak tests.

Appraximately 3,000,000 feet of electrical cable has now been pulled by CPFF forces in the 105-N and 109-N Buildings. This represents approximately 40 per cent of the total required. Previous reports on this item have included only the 105 and 109 inter-tie cables. The number reported now includes all of the CPFF electrical work in both the 105-N and 109-N Buildings.

The installation of tubing has been making better progress on all instrument systems. The automatic welding machine is being utilized on Inconel tubing welding for the mupture monitor system and is working quite well. At the present time, approximately 4,500 welds have been completed on the Inconel and stainless steel tubing for the mupture and flow monitor systems.

Work is underway on the installation of the transducer panels for the flow monitor system with tubing being installed to these panels and the electrical trays being mounted.

The production of stainiess steel tubing at Tube Methods is now lagging badly behind schedule with the reject rate running approximately 40 per cent. Only about 15 per cent of the tubing on this order has been shipped.

Pile gas panel "A" has been set in place in the control room, however, the panel has suefered extensive damage apparently in transit. Agreement has been reached with Kaiser Engineers and General Dynamics in removing the major instrument devices and shipping them to the factory for repair and doing the tubing and wiring repair work on site.

Nine (9) pieces of equipment were received this month for the temperature monitor and data logger. The installation of RTD cables for the temperature monitor system was started in the left outlet pipe space. Twenty-four of these cables had been installed by December 19, 1962. 


\section{II7-N Building}

The remaining work on this bullding by the subcontractor consists of cleanup of minor items.

\section{Pile Erection}

Forty-five horizontal rod drive assemblies have been installed and aligned in the right side rod room. All rod components have also been installed in the inner rod room on this side.

Installation of the Butterfly valves on the left inlet pipe headers has been basically completed except for about 30 where repair of the Grayloc hub seal surfaces is required on the header nozzles.

Refinishing of the Grayloc hubs on the left outlet pipe headers is continuing.

The hydraulic piping for the ' $W$ ' elevator has been flushed and is now complete.

All ball safety system trip mechanisms and plug assemblies have been installed in the top shield of the reactor.

\section{Primary Piping}

Six hundred and sixty-two spools have now been shipped to the fleld from the HUICO Shop. This represents a total weight of 715.8 tons.

Based on the total number of spools needed for completion of the Primary Piping System, excluding connectors, the following figures represent the percentares of shop-fabricated spools shipped to the field.

$$
\begin{array}{ll}
105 \text { Building } & 69.0 \% \\
109 \text { Bullding } & 62.8 \% \\
\text { Total System } & 65.7 \%
\end{array}
$$

Total spools completed and accepted by General Electric at the HUICO Shop now stands at 809 or 80 per. cent.

\section{NPR Testing Program}

Custody of certain 100-N Plant facilities were transferred from Kaiser Engineers to General Electric Company on December 17, 1962. Specific facilities involved in this transfer are 108, 151, 153, $163,166,181,183,184$ and those portions of the 182, 1503 and 1900 Area systems which are required to provide operational continuity in the major facilities enumerated. Third party certification of the 184-N boiler was received December 27, 1962. 
Planning and scheduling related to test preparation and performance is continuing with the of jective of completing test requirements within the time available and with the level of manpower which can be applied to this effort. The first two procedures are now in rcugh draft form and it is antlclpated that formal testing of certain facilities will be inftiated in January.

Administration

The following material has been processed during the perlod of November 26 through December 16, 1962.

\author{
Drawing \\ Criteria \\ Specifications \\ Requifitions \\ ATP's \\ Other
}

Total

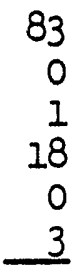

105

Reviews were completed and formal comments were offered on engineering material as follows.

\begin{tabular}{lr} 
Drawings & 0 \\
Specifications & 0 \\
Scope & 0 \\
AIP's & 0 \\
\multicolumn{1}{c}{ Total } & 0
\end{tabular}

Bailey Meter material processed as of December 16, 1962, is as fcilows.

\footnotetext{
Released as noted for Fabrication Drawings 116 Released for Information 111 Relieased for Fabrication Drawings 114 Not Reieased for Fabrication Drawings I (B\&R)

Approved without Exceptions (GE) Not Approved (GE)

Totail

Following is the status of Subcontract KE-11252 (HUICO) data as of
} 0 0 December 17, 1962. 
Total Number Recelved

2791

(Includes 2001 Recaiver For

Information only)

Number Approved

Number Approved with Exceptions

Number Not Approved

22

Number Currently Being Revlewed

3

By GE \& B\&R jointly

By B\&R (109-N)

Number Received For Information only

(No Approval Required)

2001 


\section{PROGRAM EVATTAATION}

Desigr Status

Tit.Is I - 100 per cent complete.

Titis II - 100 per cent complete.

Costs

On December 26, 1962, HOO-AEC issued a letter initlating a revised Official Budget Estimate for Project CAI-816 of $\$ 188,320,000$. (Budget Estimate for NPR supporting facility projects has been revised from a total of $\$ 7,200,000$ to a new total of $\$ 6,800,000$.

On December 18, 1962, Work Authority Number CAI-816 (N-1) for $\$ 10,000$ was Issued as an interim authorization for completion of punch list items; this wes supplemented on Derember 26, 1962, by Work Authority Number CAI-815 (N-1A) f'or a. new total interim authcrization of $\$ 160,000$.

\section{Schedules}

HOO-AEC has issued a letter stating that March 15,1964 is to be established as the official completion date for Project CAI-816. Kaiser Engineers have been instructed to complete their Revised Constmuction Schedule by January 22, 1963.

The construction status as of $1 / 1 / 63$, based on Revision \# 4 to the AEC Construction. Schedule, dated April 13, 1962, is as follows:

\begin{tabular}{|c|c|c|}
\hline & Scheduled & Actua] \\
\hline 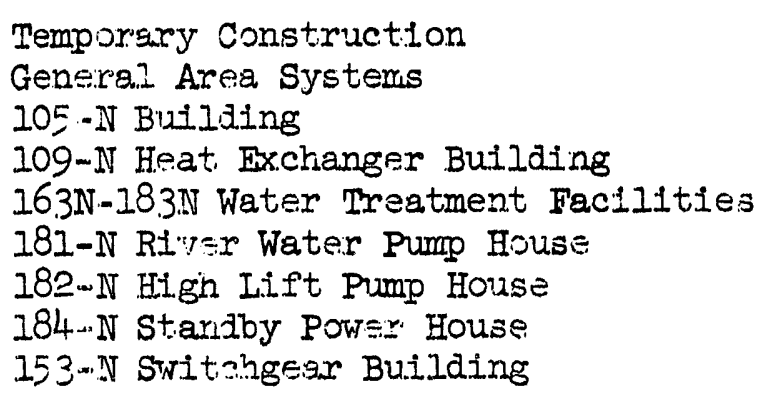 & $\begin{array}{l}88 \\
8.3 .1 \\
89 \\
91 \\
100 \\
100 \\
9.9 \\
98 \\
96\end{array}$ & $\begin{array}{l}88.0 \\
77 \cdot 5 \\
74.0 \\
72.4 \\
97.4 \\
99.4 \\
99.1 \\
99.0 \\
99.3\end{array}$ \\
\hline NPR Projact (CAT 816) & 88 & 73.3 \\
\hline
\end{tabular}

IS McMakon:mf 

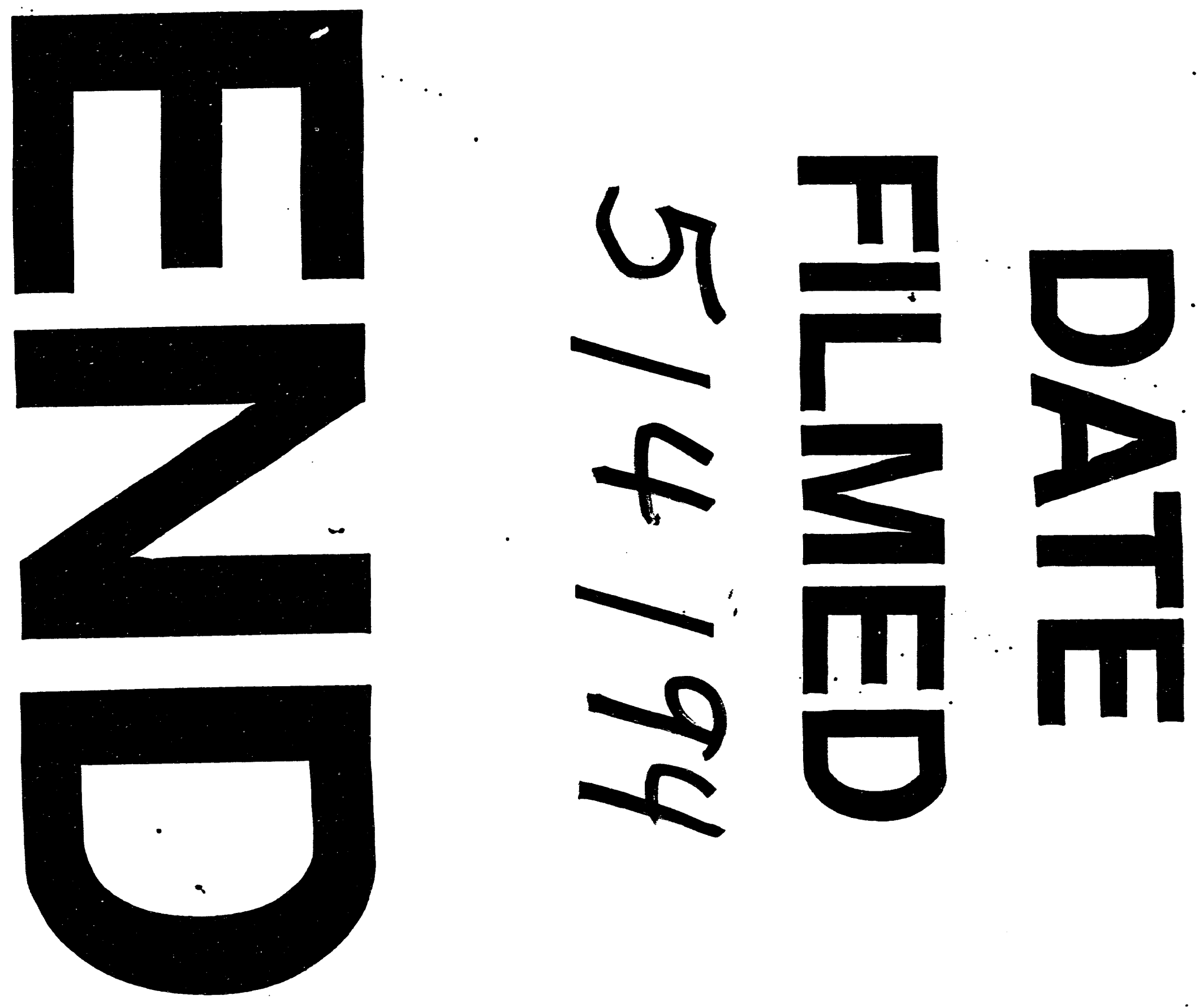
